\title{
Potential of Zerumbone as an Anti-Cancer Agent
}

\author{
Sosmitha Girisa ${ }^{1}$, Bano Shabnam ${ }^{1}$, Javadi Monisha ${ }^{1}$, Lu Fan ${ }^{2}$, Clarissa Esmeralda Halim ${ }^{2}$, \\ Frank Arfuso $^{3}{ }^{(}$, Kwang Seok Ahn ${ }^{4, *} \mathbb{C}$, Gautam Sethi ${ }^{2, *}$ and Ajaikumar B. Kunnumakkara ${ }^{1, *}$ \\ 1 Cancer Biology Laboratory, DBT-AIST International Laboratory for Advanced Biomedicine (DAILAB), \\ Department of Biosciences \& Bioengineering, Indian Institute of Technology, \\ Guwahati, Assam 781039, India; sosmi176106101@iitg.ac.in (S.G.); bano176106104@iitg.ac.in (B.S.); \\ j.monisha@iitg.ernet.in (J.M.) \\ 2 Department of Pharmacology, Yong Loo Lin School of Medicine, National University of Singapore, \\ Singapore 117600, Singapore; phcfanl@nus.edu.sg (L.F.); phsceh@nus.edu.sg (C.E.H.) \\ 3 Stem Cell and Cancer Biology Laboratory, School of Pharmacy and Biomedical Sciences, Curtin Health \\ Innovation Research Institute, Curtin University, Perth, WA 6102, Australia; frank.arfuso@curtin.edu.au \\ 4 College of Korean Medicine, Kyung Hee University, 24 Kyungheedae-ro, Dongdaemun-gu, \\ Seoul 02447, Korea \\ * Correspondence: ksahn@khu.ac.kr (K.S.A.); phcgs@nus.edu.sg (G.S.); kunnumakkara@iitg.ac.in or \\ ajai78@gmail.com (A.B.K.); Tel.: +82-2-961-2316 (K.S.A.); +65-6516-3267 (G.S.); +91-361-258-2231 (A.B.K.); \\ Fax: $+65-6873-7690$ (G.S.); +91-361-258-2249 (A.B.K.)
}

Academic Editor: Roberto Fabiani

Received: 21 December 2018; Accepted: 16 February 2019; Published: 18 February 2019

\begin{abstract}
Cancer is still a major risk factor to public health globally, causing approximately 9.8 million deaths worldwide in 2018. Despite advances in conventional treatment modalities for cancer treatment, there are still few effective therapies available due to the lack of selectivity, adverse side effects, non-specific toxicities, and tumour recurrence. Therefore, there is an immediate need for essential alternative therapeutics, which can prove to be beneficial and safe against cancer. Various phytochemicals from natural sources have been found to exhibit beneficial medicinal properties against various human diseases. Zerumbone is one such compound isolated from Zingiber zerumbet Smith that possesses diverse pharmacological properties including those of antioxidant, antibacterial, antipyretic, anti-inflammatory, immunomodulatory, as well as anti-neoplastic. Zerumbone has shown its anti-cancer effects by causing significant suppression of proliferation, survival, angiogenesis, invasion, and metastasis through the molecular modulation of different pathways such as NF-kB, Akt, and IL-6/JAK2/STAT3 (interleukin-6/janus kinase-2/signal transducer and activator of transcription 3) and their downstream target proteins. The current review briefly summarizes the modes of action and therapeutic potential of zerumbone against various cancers.
\end{abstract}

Keywords: zerumbone; cancer; apoptosis; NF-kB; IL-6/JAK2/STAT3; Akt; FOXO1

\section{Introduction}

Cancer is a serious health problem globally and is the second leading cause of death [1-5]. The risk factors for cancer mortality may be due to behavioural and environmental factors such diet, exposure to air pollution, use of addictive substances, lack of physical activity, etc. [6]. The recent targeted therapies for cancer are associated with non-specific toxicities, exhibit limited efficacy, and are expensive to use [7]. Also, one of the major drawbacks of anti-cancer drugs has been the lack of selectivity, and thus they can exert adverse effects on the healthy tissues and organs [8]. Furthermore, conventional chemotherapeutics are also associated with the development of chemoresistance [9-12]. Overall, most cancer treatment strategies are associated with side effects, lack of selectivity, toxicity, 
and development of chemoresistance, leading to high mortality and poor prognosis [7-13]. Herbs, vegetables, fruits, spices, cereals, pulses, and nuts have been shown to produce a large number of phytochemicals that exert chemopreventive and therapeutic properties against various human ailments [14-29]. Since ancient times, plants and plant-based compounds have been extensively used in tribal and folklore medicine due to their beneficial pharmacological properties and fewer side effects [20,30-32]. One such plant-derived compound is zerumbone (Figure 1), extracted from the traditional plant Zingiber zerumbet Smith, which is also known as bitter ginger, shampoo ginger, and pinecone ginger [33-38].

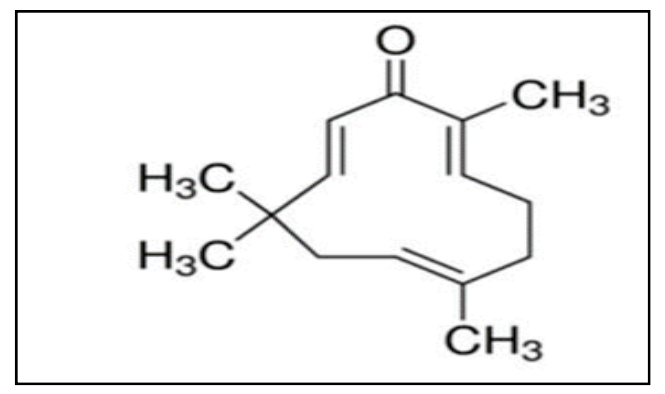

Figure 1. Structure of zerumbone [38].

Traditionally, the rhizomes of Z. zerumbet are widely used as a food flavouring agent and appetizer in various cuisines; it is also used in herbal folk medicine and pain relief [37-40]. Zerumbone is known for its biomedical properties such as being antioxidant, antibacterial, antipyretic, antinociceptive, anti-hypersensitive, anti-inflammatory, as well as possessing hepatoprotective, and immunomodulatory activities [16,17,41-44]. Besides the aforementioned properties, zerumbone can also function as an antitumor drug exhibiting its diverse effects on proliferation, angiogenesis, and apoptosis against various cancer cell lines, which has drawn the attention of many researchers [45-47]. Zerumbone (2,6,9,9-tetramethyl-(2E,6E,10E)-cycloundeca-2,6,10-trien-1-one) is a crystalline sesquiterpene compound containing an 11-membered ring with three double bonds at C6, C2, and C10, forming part of a cross-conjugated ketone system that participates in its biological activity [48-51]. A number of prior studies have elaborated upon the potential anti-allergic, immunomodulatory, and anti-cancer properties of zerumbone. The present review summarizes the anti-cancer properties of zerumbone along with its mode of actions and molecular targets in different cancer types.

\section{Molecular Targets of Zerumbone against Cancer}

It is now well established that cancer arises as a result of dysregulation of multiple cellular pathways. Therefore, multi-targeted compounds have high potential in the prevention and treatment of cancer $[2,5,18,26,52-58]$. Increasing lines of evidence suggest that zerumbone can act on multiple pathways and can suppress the growth of cancer cells. With regard to this, in melanoma zerumbone treatment downregulated Bcl-2 (B-cell lymphoma 2), upregulated Bax (BCL2 associated X protein), cytochrome c gene-related proteins, and activated caspase-3 [59]. In addition, zerumbone decreased cell viability through the downregulation of cyclin B1, cyclin-dependent kinase (CDK)-1, Cdc25C, and Cdc25B, and induced apoptosis by significantly activating Bax and Bak proteins in breast cancer [60]. Moreover, zerumbone downregulated CXCR4 expression on human-epidermal growth factor receptor-2 (HER2)-overexpressing breast cancer cells by abrogating NF-kB activation which correlated with the arrest of invasion and metastasis induced by CXCL12 expression [61]. In addition, zerumbone could also activate caspase-3 and poly (ADP-ribose) polymerase (PARP) production and reduced Akt phosphorylation, which increased cell death induction in glioblastoma [62]. Further, the treatment of zerumbone on mouse epidermal JB6 cells can induce an increase in NF-E2-related factor 2(Nrf2) nuclear translocation complemented by the upregulation of heme oxygenase-1 (HO-1), 
causing Nrf2 to bind directly to the antioxidant response element, and thus exert chemopreventive effects against mouse skin carcinogenesis [63]. In addition, zerumbone inhibited breast cancer and multiple myeloma-induced osteoclast formation through suppression of activated IkappaBalpha (IкB $\alpha$ )

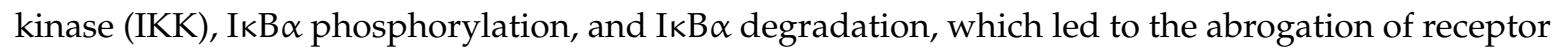
activator of nuclear factor kappa-B ligand (RANKL)-induced NF- $\mathrm{KB}$ activation, which serves as a major mediator for bone resorption [64]. Zerumbone could also induce apoptosis in leukemic cells through the initiation of the cleavage of Bid, Bax, and Mcl-1 proteins, loss of the mitochondrial transmembrane potential, and activation of caspase-3 and -9, leading to degradation of PARP [65].

Natural products possess several properties, which enable them to fight against various cancer cell types [34,66]. Zerumbone possesses antiproliferative properties against various cancers such as brain, breast, cervical, colon, liver, lung, pancreas, and skin cancer $[3,67]$. The reported anti-tumour activities of zerumbone against different malignancies are briefly summarized below.

\subsection{Zerumbone and Brain Tumor}

Brain tumors are the leading cause of cancer-related death in children $[68,69]$. The incidence of primary malignant brain tumours is increasing, of which $80 \%$ consist of high-grade malignant tumors such as glioblastoma multiforme (GBM) [70]. Prior studies have reported that treatment with zerumbone suppressed FOXO1 and Akt phosphorylation due to inactivation of IKK $\alpha$ while activating caspase-3 protein and PARP, which resulted in decreased cell viability, and induction of apoptosis in GBM cells [62].

\subsection{Zerumbone and Breast Cancer}

Breast cancer is the most common and highly complex cancer associated with poorest clinical outcome in women worldwide [71-76]. Among the various subtypes, triple-negative breast cancer (TNBC) is the most aggressive form and, occurs in young age pre-menopausal women [77,78]. Triple-negative breast cancer fails to express the estrogen receptor (ER), human-epidermal growth factor receptor-2 (HER2) proteins, and progesterone receptor (PR) [77]. Zerumbone was found to increase the induction of presenilin-1 protein and transcriptional activation of Notch, leading to cleavage of Notch2. In addition, there was a reduction in cleaved Notch1 and Notch4 proteins, which resulted in increased apoptosis and suppression of cellular migration [79]. Zerumbone also decreased the levels of IL-8 and MMP-3 expression through the downregulation of NF-kB activity, which led to reduction in IL-1 $\beta$-induced cell migration and invasion in TNBC $[72,80]$. Zerumbone induced G(2)/M cell arrest and Bax/Bak-mediated apoptosis [60]. Zerumbone also inhibited invasion and metastasis in breast cancer by downregulating the expression of CXCR4 [61]. Further, zerumbone suppressed TGF- $\beta 1$-induced FN, MMP-2, and MMP-9 expression through the decreased phosphorylation of TGF- $\beta 1$-induced Smad3, and also inhibited Ki67 expression [77].

Further, in mouse xenografts, zerumbone treatment was noted to reduce the tumor growth [60]. In addition, zerumbone decreased breast cancer-associated osteolysis in athymic nude mice with MDA-MB-231 breast cancer [64]. The mice treated with $20 \mathrm{mg} / \mathrm{kg}$ of zerumbone were observed to develop significantly smaller tumors than the control group treated with vehicle. Thus, zerumbone mitigated the tumorigenicity by reducing tumor volume and weight, and metastasis in xenograft models of TNBC [77].

\subsection{Zerumbone and Colorectal Cancer}

Colorectal cancer $(\mathrm{CRC})$ is the third-leading cause of cancer-related deaths after lung and breast cancer [81,82]. Zerumbone inhibited the proliferation of colon cancer cells and thereby induced apoptosis, which might be due to mitochondria transmembrane dysfunction, translocation of phosphatidylserine, and chromatin condensation [83]. Zerumbone downregulated the expression of FLICE-like inhibitory protein (cFLIP); and in the presence of both Bax and p21, stimulated tumor necrosis factor-related apoptosis-inducing ligand (TRAIL) death receptor (DR) 4 and 
DR5, which intensified TRAIL-induced apoptosis in human HCT116 colon cancer cells, thus resulting in the enhanced anticancer effects of TRAIL [84]. Zerumbone pre-treatment inhibited the expression of radiation-induced DNA repair proteins ataxia-telangiectasia mutated (ATM) and DNA-PKCs through glutathione (GSH) depletion, leading to cell cycle arrest (G2/M) and increase in apoptosis, thus enhancing radiosentitivity of CRC cells [82]. Zerumbone induced IL-1 $\beta$ pathways through the expression of interleukin (IL)- $1 \alpha$, IL-1 $\beta$, IL-6, and tumor necrosis factor (TNF)- $\alpha$, which might be associated with the activation of c-Jun $\mathrm{N}$-terminal kinase and extracellular signal-regulated protein kinase [85]. Further, zerumbone treatment on HCT-116 and SW48 cells showed its anti-metastatic potential through the inhibition of Fak/PI3k/NF-kB-uPA pathway [86].

Oral administration of zerumbone at 100,250, and $500 \mathrm{ppm}$ for the duration of 17 weeks to the mice significantly inhibited the multiplicity and inflammation in colonic adenocarcinomas through the repression of NF- $\mathrm{kB}$ and heme oxygenase (HO)-1, which resulted in suppression of the proliferation and induction of apoptosis [87].

\subsection{Zerumbone and Cholangiocarcinoma}

Cholangiocarcinoma (CCA) is an aggressive and deadly malignant tumor arising in the bile duct epithelial cells [88-90]. It is characterized by a high degree of genetic instability contributing to a heterogeneous malignant phenotype, and this variation is related to the distribution of different risk factors [91,92]. Surgical resection continues to be the best therapeutic approach for patients with CCA. Nevertheless, it is often associated with poor prognosis, and due to lack of early diagnostic evidence, most patients are not suitable for surgery [93]. The inhibition of CDK-2, CDK-5 or EGFR could result in reduction in CCA cell proliferation, and previous reports have revealed the overexpression of CDK-2, CDK-5 or EGFR in CCA. Molecular docking studies have demonstrated that derivatives of zerumbone with the presence of amine, epoxyamine, hydroxylamine, and nitrile groups can exhibit potent anti-cancer activities against CCA cells by interacting with the molecular target EGFR, but not CDK-2, CDK-5, and GSK-3. The derivative with the presence of an amine group has shown higher potency against proliferation of cancer cells through the inhibition of EGFR [49].

\subsection{Zerumbone and Gastric Cancer}

Gastric cancer is the fourth most common malignant tumor and second main cause of cancer deaths in both sexes worldwide [13,94-98]. Zerumbone could induce apoptosis in gastric cancer cells by blocking the activity of cyclophilin A and subsequently promoting mitochondrial pathway-mediated apoptosis. The mitochondrial pathway caused cyt $C$ release from the mitochondria into the cytoplasm, leading to caspase-3 activation, which acted as an effector molecule for caspase-dependent apoptosis [13]. In addition, zerumbone caused inhibition of cell proliferation and tube formation area of human umbilical vein endothelial cells through the reduction in expression of vascular endothelial growth factor (VEGF) and NF- $\mathrm{kB}$ activities, and thereby inhibiting angiogenesis [99].

\subsection{Zerumbone and Leukemia}

Leukemia is the most common cancer that occurs in the blood forming tissues $[5,100]$. Zerumbone was reported to reduce the proliferation of leukemic cells by inducing G2/M cell cycle arrest through suppression of cyclin B1/cdk 1 protein along with the phosphorylation of ATM/Chk1/Chk2, followed by apoptosis via initiation of Fas (CD95)/Fas Ligand (CD95L) expression associated with caspase- 8 activation $[65,101]$. Analogous to the abovementioned anti-proliferative effects, the use of a zerumbone-loaded nanostructured lipid carrier (NLC) arrested Jurkat cells in the G2/M phase via inactivation of cyclin B1 protein and activation of intrinsic apoptotic proteins (i.e., caspase-3 and caspase-9), and release of cytochrome $c$ with subsequent cleavage of PARP [102,103]. Zerumbone-NLC also induced activation of the mitochondrial-dependent apoptotic pathway in murine leukemic cells [104]. Zerumbone inhibited K562 chronic myelogenous leukemic cell proliferation and colony formation, with induction of DNA damage and mitochondria mediated apoptosis through 
the activation of pro-caspase-3, -9, and PARP cleavage, with an increase in free intracellular $\mathrm{Ca}^{2+}$, ROS, and soluble histone-H2AX (H2A histone family member X) upregulation [105]. Additionally, zerumbone exerted a cytotoxic effect against CEM-ss leukemic cells by producing characteristics of apoptosis such as membrane blebbing, holes, and cytoplasmic extrusions [100].

\subsection{Zerumbone and Liver Cancer}

Hepatocellular carcinoma (HCC) is one of the most prevalent and highly aggressive liver malignancy [106-114]. Zerumbone has been shown to cause the inhibition of HCC cells proliferation by G2-M cell cycle arrest through the inhibition of PI3K/AKT/mTOR and signal transducer and activator of transcription 3 (STAT3) signalling pathways leading to the induction of apoptosis [115]. Zerumbone also inhibited the proliferation and migration of a liver cancer HepG2 cell line by significantly decreasing the expression of the MMP-9, VEGF, and VEGF receptor proteins in a dose-dependent manner [116]. Further, zerumbone exhibited also induced apoptosis via upregulation of Bax and suppression of Bcl-2 protein expression on HepG2 cells [117]. In line with the above, zerumbone treatment in DEN/AAF (diethylnitrosamine/2-acetylaminofluorene) rat livers induced mitochondria-regulated apoptosis by increasing Bax and decreasing Bcl-2 protein expression, along with a reduction of oxidative stress and an inhibition of proliferation, and thereby minimizing DEN/AAF-induced carcinogenesis [67]. Zerumbone can activate the Nrf2/ARE-dependent detoxification pathway induced by nuclear localization of Nrf2, which can bind to the antioxidant response element of the phase II enzyme genes, thereby suggesting an antioxidant role of zerumbone in neutralizing lipid peroxidation in liver cells to put a stop to cancer [48]. A soluble complex of zerumbone with hydroxypropyl- $\beta$-cyclodextrin (HP- $\beta-C D)$ induced apoptosis and G2/M arrest along with the release of cytochrome $\mathrm{c}$ and loss of mitochondrial membrane potential, with a significant increase in caspase $3 / 7$, caspase 9 , and caspase 8 , and with the depletion of BID that is cleaved by caspase 8 [118].

\subsection{Zerumbone and Lung Cancer}

Lung cancer is one of the most common malignancies and leading cause of cancer-related death worldwide [119-122]. About $80 \%$ of diagnosed lung cancer is non-small cell lung cancer (NSCLC), which ranks top in both incidence and mortality [123,124]. Zerumbone induces apoptosis through loss of mitochondrial membrane potential, release of cytochrome c, caspase- 9 and -3 activation, increased expression of p53 and Bax, and increased ROS production, and zerumbone also sensitized NSCLC cells to cisplatin [125].

Further, dietary administration of zerumbone at 250 and $500 \mathrm{ppm}$ to the mice for 21 weeks was found to significantly inhibit the multiplicity of lung cancer in a dose-dependent manner. The suppression of lung carcinogenesis was caused through the reduction of growth, decreased inflammation, and decreased expression of NF- $\mathrm{kB}$ and HO-1, thereby causing apoptosis [87].

\subsection{Zerumbone and Oral Cancer}

Oral cancer is a serious cancer in developing countries and many parts of the globe, with varying incidence rate according to geographic regions [126,127]. It affects approximately 274,000 people worldwide annually and the pattern of use of tobacco products usually marks the frequency of occurrence [128]. Zerumbone treatment inhibited cell proliferation, migration, and invasion in oral squamous cell carcinoma by suppressing the expression of CXCR4, RhoA proteins, and PI3K-mTOR signalling pathway, causing G2/M cell cycle arrest followed by apoptotic activity. The inhibition of the PI3K-mTOR signalling pathway was associated with the suppression of Akt and S6 proteins [129].

\subsection{Zerumbone and Cervical and Ovarian Cancer}

Cervical cancer ranks as the second most common cause of cancer death among women [130]. Zerumbone along with cisplatin treatment can stimulate apoptosis by arresting cells at the G2/M 
phase and decreasing the levels of IL-6 in HeLa and Caov-3 cells [131]. Zerumbone also downregulated the expression of proliferating cellular nuclear antigen, thus revealing its antitumor effect on human cervical cancer cells [132]. Similarly, zerumbone can induce apoptosis by causing regression of cervical intraepithelial neoplasia (CIN) tissues in female Balb/c mice treated with diethylstilbestrol, which showed an effect resembling that of cisplatin, through the modulation of Bax and Bcl-2 genes [130]. Zerumbone showed its cytotoxic property on HeLa cells by increasing cellular caspase-3 levels and producing distinct morphological features of apoptotic death such as nuclear and chromatin condensation, cell shrinkage, membrane blebbing, abnormalities of mitochondrial cristae, multinucleation, and formation of apoptotic bodies [133].

Also, the combination of zerumbone with cisplatin has been shown to cause regression of (CIN) via modulation of the IL-6 level in the serum of female Balb/c mice. Four groups of mice were taken for the treatment along with a group with no treatment from 52 days of age to 60 days of age with four dosages on alternate days. Group 1 mice were treated with $0.9 \%$ normal saline for the positive control while group 2 and group 3 mice were administered with $8 \mathrm{mg} / \mathrm{kg}$ and $16 \mathrm{mg} / \mathrm{kg}$ of zerumbone, respectively. The mice representing group 4 was treated with $10 \mathrm{mg} / \mathrm{kg}$ while group 5 was given no treatment to act as a negative control. Both the compounds, at their mentioned effective dosages were able to regress the progression of cancerous cervix tissues [130].

\subsection{Zerumbone and Pancreatic Cancer}

Pancreatic carcinoma is a common cancer with a gradual increase in incidence rate [134]. Treatment of pancreatic cancer cells with zerumbone inhibited tube formation of human umbilical vein endothelial cells through the suppression of mRNA expression and proteins associated with angiogenic function and NF- $\mathrm{KB}$ activity [135]. Further, zerumbone reduced cell viability and induced apoptosis in PANC-1 cells, as evidenced the upregulated expression of p53, p21 protein, and elevated ROS levels [134]. In addition, zerumbone caused downregulation in the expression of CXCR4, which correlated with suppression of CXCL12-induced invasion [61].

\subsection{Zerumbone and Prostate Cancer}

Prostate cancer is the one of the most common causes of malignancy in males, and is without curative options in the advanced state [136-143]. Pre-treatment of prostate cancer cells with zerumbone significantly decreased the radiation-induced expression of phosphorylated ATM (ataxia telangiectasia-mutated) and suppressed the expression of JAK2 and STAT3, which are involved in DNA damage repair [144]. In addition, zerumbone selectively inhibited the IL-6/JAK2/STAT3 pathway and blocked the prostate cancer-associated genes- cyclin D1, IL-6, COX2 (cytochrome c oxidase), and ETS Variant 1 (ETV1); thereby inducing cytotoxicity through G0/G1 cell cycle arrest and causing apoptosis [145]. Zerumbone also attenuated microtubule assembly and induced endoplasmic reticulum (ER) stress and MMP-2 expression in prostate cancer cells and upregulated the expression of GRP-78 and C/EBP homologous protein (CHOP)/ growth arrest and DNA damage 153 (GADD153). An increase in intracellular $\mathrm{Ca}^{2+}$ levels potentially acted as a crosstalk marker between this ER stress and mitochondrial insult, which was associated with the formation of the active calpain I fragment. Zerumbone also induced apoptosis and autophagy through the caspase-dependent pathway and LC3-II formation [43].

\subsection{Zerumbone and Renal Cell Carcinoma}

Renal cell carcinoma (RCC) is a malignant disease insensitive to conventional treatments, contributing $>90 \%$ of the most common form of kidney cancer $[146,147]$. Zerumbone showed its anti-cancer effects by initiating apoptosis through the activation of caspase- 3 and caspase- 9 , leading to cleavage of PARP and downregulation of Gli-1 and Bcl-2 [146]. In addition, zerumbone could induce the expression of tyrosine phosphatase SHP-1(Src homology region 2 domain-containing 
phosphatase-1), which has been associated with inhibition of STAT3 activation thereby resulting in the suppression of the gene products that are involved with proliferation, survival, and angiogenesis.

In line with the above, similar abrogation of STAT3 activation was exhibited in tumor growth and tissues upon administration of zerumbone in athymic nu/nu mice with an RCC xenograft. For this, the tumor tissues were treated with vehicle and $50 \mathrm{mg} / \mathrm{kg}$ body weight of zerumbone for 6-week duration and substantial inhibition of STAT3 activation was noted [148].

\subsection{Zerumbone and Skin Cancer}

Skin cancer is the most commonly diagnosed cancer that begins with an abnormal growth in the epidermal layer, and can be classified as melanoma and non-melanoma skin cancer [149]. Pre-treatment with zerumbone at the tumor promotion stage in mice suppressed tumor growth and the mechanism behind its effect might be due to increased expression of xenobiotic-metabolizing enzymes (GSTP1, NQO1) and mRNA levels for manganese superoxide dismutase (MnSOD) and glutathione peroxidase-1 (GPx1). In addition, zerumbone decreased the levels of cyclooxygenase-2 (COX-2) expression, ERK1 phosphorylation, $\mathrm{H}_{2} \mathrm{O}_{2}$-induced edema formation, and leukocyte infiltration [150].

Further, treatment of epidermal cells with zerumbone in mice enhanced the binding property of Nrf2 to the antioxidant element, which resulted in increased HO-1 activity, thus providing a basis for the reported antioxidant effects of this agent against skin carcinogenesis [63].

\section{Cytotoxicity Data}

The cytotoxicity data has been analyzed for both the in vitro and in vivo studies. The treatment of zerumbone on various cancers was reported to be effective in various in vitro studies. For the liver cancer, the $\mathrm{IC}_{50}$ of zerumbone in HepG2 cells was reported to be $6.20 \mu \mathrm{g} / \mathrm{mL}$ [116]. While the $\mathrm{IC}_{50}$ for cervical cancer in Hela cells was reported to be $6.4 \mu \mathrm{g} / \mathrm{mL}$, and in breast cancer cell lines (MCF-7 and MDA-MB 231) $23.0 \mu \mathrm{g} / \mathrm{mL}$ and $24.3 \mu \mathrm{g} / \mathrm{mL}$ respectively [151]. In case of the in vivo studies, zerumbone suppressed the tumor growth and volume in different cancers with different dosage rates. In line with this, the treatment of zerumbone for a 6-week duration caused tumor growth inhibition in renal cancer model, the dosage was five times a week with $50 \mathrm{mg} / \mathrm{kg}$ body weight. The treatment also showed less substantial toxic effects as it did not cause weight loss in treated mice [148] while in cervical cancer models different groups were administered with $4 \mathrm{mg} / \mathrm{kg}$, $8 \mathrm{mg} / \mathrm{kg}$, and $16 \mathrm{mg} / \mathrm{kg}$ of zerumbone respectively. No remarkable regression of the CIN lesions was observed with $4 \mathrm{mg} / \mathrm{kg}$ dosage as compared to the later dosages. The dosage of $8 \mathrm{mg} / \mathrm{kg}$ showed antiproliferative properties while $16 \mathrm{mg} / \mathrm{kg}$ showed decreased in CIN lesions [130]. The dosage of zerumbone in breast cancer can also be compared where the mice models were treated with $20 \mathrm{mg} / \mathrm{kg}$ of zerumbone which resulted to smaller tumors than the control group treated with vehicle. The weight level of tumor in zerumbone treated mice was lesser with $1.22 \pm 0.35 \mathrm{~g}$ as compared to the mice treated with vehicle that weighed $2.56 \pm 0.68 \mathrm{~g}$ [77]. In case of colon and lung cancer studies, the mice models were injected with azoxymethane $(10 \mathrm{mg} / \mathrm{kg} \mathrm{bw})$, promoted by $1.5 \%$ dextran sulphate sodium in drinking water for 7 days to initiate colon tumour while the other models were injected with 4-(methylnitrosamino)-1-(3-pyridyl)-1-butanone (10 micromol/mouse) to induce lung tumor. Both the tumor models were later administered with zerumbone at 100, 250, and 500 ppm for 17 weeks and 21 weeks, respectively, that resulted in inhibition of multiplicity the cancers [87].

\section{Limitation and Future Prospects}

Various potential studies of zerumbone against different tumor cell lines have been reported. However, most of the reports are mainly confined to in vitro studies. Few in vivo model studies are reported in only few cancers such as breast, colorectal, cervical, lung, renal cell carcinoma, and skin cancers. Also, relevant clinical trials to test the safety and efficacy of zerumbone are not available. The limitations in clinical studies might be due to few in vivo model findings. Further, the pharmacokinetic properties such as solubility, distribution, etc. of the compound should be 
analysed properly. A previous study that aimed to enhance the solubility of zerumbone was explored to analyse its interaction with hydroxypropyl- $\beta$-cyclodextrin $(\mathrm{HP} \beta C \mathrm{C})$ in aqueous media where it was showed that the solubility of zerumbone substantially increased with an augmentation in the concentration of $\mathrm{HP} \beta \mathrm{CD}$ at $20{ }^{\circ} \mathrm{C}$ thereby suggesting that this complexation can be used in this drug formulation [50].

Therefore, apart from in vitro and in vivo studies, the pharmacokinetic properties of zerumbone can be investigated and established, and also clinical trial studies can be carried out further to validate its therapeutic application in cancer patients.

\section{Conclusions}

Despite the advancement in treatment methods, cancer is still one of the deadliest diseases causing havoc to human health. Most of the treatment methods available are less effective and often associated with severe side effects and emergence of chemoresistance. Therefore, it is essential to discover a new alternate, safe, and efficacious treatment method against cancer. Zerumbone, a monocyclic sesquiterpene, isolated from Z. zerumbet is a compound that has been reported for its diverse anti-cancer properties mediated by suppression of proliferation, induction of cell cycle arrest, and apoptosis in various cancers such as those of brain, breast, colon, liver, and lung through the modulation of various proteins and signalling pathways (Table 1). With regard to this, various in vitro studies have shown that zerumbone can downregulate the expression CXCR4, activation of NF- $\mathrm{KB}$, and other oncogenic proteins. Additionally, zerumbone can also repress the IL-6/JAK2/STAT3, $\mathrm{PI} 3 \mathrm{~K} / \mathrm{AKT} / \mathrm{mTOR}$ pathways, and expression of associated genes such as cyclin D1, IL-6, COX2, and ETV1, thus inhibiting proliferation and angiogenic activity by increasing cell cycle arrest and apoptosis. Moreover in preclinical studies, administration of zerumbone in various mouse models was observed to tumor growth and metastasis. However, despite the availability of many pre-clinical studies on the anti-cancer properties of zerumbone, clinical trials with this compound have been rarely reported. Therefore, more preclinical studies would be required to establish clinical results and a better therapeutic potential of zerumbone, to target cancer. 
Table 1. Possible role of zerumbone against various cancers.

\begin{tabular}{|c|c|c|c|c|}
\hline Cancer & In Vitro/In Vivo & Model & Mechanism of Action & Reference \\
\hline \multirow[t]{10}{*}{ Breast cancer } & In vitro & $\begin{array}{l}\text { MDA-MB-231, MDA-MB-468, MDA-MB-361, } \\
\text { T-47D }\end{array}$ & $\downarrow \mathrm{CD} 1 \mathrm{~d}$ & [152] \\
\hline & In vitro & MCF7, Hs578T, MDA-MB231 & $\downarrow \mathrm{IL}-1 \beta$ & [72] \\
\hline & In vitro & HCC1806 & $\downarrow$ TGF- $\beta 1$ & [77] \\
\hline & In vitro & SKBR3, MDA-MB468 & $\downarrow$ CD $44, \downarrow$ STAT- 3 & [71] \\
\hline & In vitro & MCF-7, MDA-MB-231 & $\downarrow$ Notch4 & [79] \\
\hline & In vitro & Hs578T, MDA-MB231 & $\downarrow$ IL-8, $\downarrow$ MMP-3 & [80] \\
\hline & In vitro & MDA-MB-231, MCF-7 & $\uparrow \mathrm{Bax}, \uparrow \mathrm{Bak}$ & [60] \\
\hline & In vivo & Mouse & $\downarrow$ Tumor growth & [60] \\
\hline & In vitro & MDA-MB-231, U266 & $\downarrow N F-\kappa B$ & {$[64]$} \\
\hline & In vivo & Athymic mice & $\downarrow$ Osteolysis & [64] \\
\hline \multirow[t]{3}{*}{ Cervical cancer } & In vitro & $\mathrm{HeLa}, \mathrm{H} 9 \mathrm{c} 2$ & $\uparrow$ Caspase 3 & [8] \\
\hline & In vivo & female BALB/c mice & $\downarrow$ Neoplasia & [133] \\
\hline & In vivo & female BALB/c mice & $\uparrow a p o p t o s i s$ & [130] \\
\hline \multirow[t]{7}{*}{ Colon cancer } & In vitro & Caco-2, Colo320DM, HT-29 & $\uparrow \mathrm{IL}-6$ & [85] \\
\hline & In vitro & HCT116 & $\downarrow \mathrm{TNF}-\alpha$ & [40] \\
\hline & In vitro & HCT116 & $\uparrow \mathrm{DR} 5, \mathrm{DR} 4$, Caspase-8 & {$[84]$} \\
\hline & In vitro & HCT-116, SW-48 & $\downarrow \beta$-catenin & [153] \\
\hline & In vitro & SW480 & $\uparrow$ caspase $3, \uparrow$ caspase $8, \uparrow$ caspase 9 & [3] \\
\hline & In vitro & HCT116 & $\downarrow$ GSH & [82] \\
\hline & In vivo & Mice & $\downarrow$ multiplicity of adenomas & [87] \\
\hline \multirow[t]{2}{*}{ Gastric cancer } & In vitro & SGC-7901 & $\downarrow \mathrm{Bcl}-2$ & [13] \\
\hline & In vitro & MKN1, MKN28, MKN45, MKN74, NUGC4, AGS & $\downarrow N F-\kappa B$ & [99] \\
\hline \multirow[t]{5}{*}{ Liver cancer } & In vitro & HepG2 & $\uparrow \mathrm{Bax}$ & [117] \\
\hline & In vitro & HepG2 & $\uparrow \mathrm{p} 27, \uparrow$ Cyt-c, $\uparrow$ caspase- 3 \& caspase- 9 & [154] \\
\hline & In vitro & HepG2 & $\downarrow$ VEGF, $\downarrow$ MMP-9 & [116] \\
\hline & In vitro & HepG2, Hep3B, Sk-Hep-1, SNU-182, SNU-449 & $\downarrow \mathrm{PI} 3 \mathrm{~K} / \mathrm{AKT} / \mathrm{mTOR}, \downarrow \mathrm{STAT}-3$ & [115] \\
\hline & In vitro & HepG2 & $\uparrow$ Cell cycle arrest & [155] \\
\hline Leukemia & In vitro & CEM-ss & $\uparrow$ Caspase-3 & [100] \\
\hline \multirow[t]{3}{*}{ Lung Cancer } & In vitro & A549 & $\downarrow$ FAK/AKT/ROCK & [38] \\
\hline & In vitro & A549, NCI-H460 & $\uparrow \mathrm{p} 53$ & [125] \\
\hline & In vivo & Mice & $\downarrow$ Carcinogenesis & [87] \\
\hline Oral cancer & In vitro & OSCC & $\downarrow$ PI3K-mTOR & [129] \\
\hline Pancreatic cancer & In vitro & $\mathrm{PaCa}$ & $\downarrow N F-\kappa B$ & [135] \\
\hline
\end{tabular}


Table 1. Cont.

\begin{tabular}{|c|c|c|c|c|}
\hline Cancer & In Vitro/In Vivo & Model & Mechanism of Action & Reference \\
\hline \multirow{3}{*}{ Prostate cancer } & In vitro & PANC-1, SW1990 & $\uparrow$ ROS & [134] \\
\hline & In vitro & PC3, DU145 & $\downarrow$ Phosphorylated ATM & [144] \\
\hline & In vitro & DU145, PC3 & $\downarrow J A K 2 / S T A T 3$ & [145] \\
\hline \multirow[t]{2}{*}{ Renal cell carcinoma } & In vitro & 786-0,769-P & $\downarrow$ Gli-1/Bcl-2 & [146] \\
\hline & In vivo & Athymic nu/nu mice & $\downarrow$ STAT3, $\downarrow$ Tumor growth & [148] \\
\hline \multirow[t]{2}{*}{ Skin cancer } & In vitro & CHL-1 & $\uparrow \operatorname{ROS}$ & [156] \\
\hline & In vitro & A375 & $\downarrow \mathrm{Bcl}-2$ & [59] \\
\hline
\end{tabular}


Author Contributions: S.G., B.S., J.M., A.B.K., and G.S. conceived the project and wrote the article. F.A., L.F., C.E.H., K.S.A. edited the manuscript. G.S., A.B.K., and K.S.A. carried out the overall supervision of work. All authors read and approved the final version of manuscript.

Funding: A.B.K. received funding (DBT/UXEL/2017) from the Department of Biotechnology, Government of India.

Conflicts of Interest: The authors declare no conflicts of interest.

\section{Abbreviations}

$\begin{array}{ll}\text { ATM } & \text { Ataxia-telangiectasia mutated } \\ \text { Bcl-2 } & \text { B-cell lymphoma- } 2 \\ \text { Bak } & \text { Bcl-2 homologous antagonist/killer } \\ \text { Bax } & \text { BCL2-associated X protein } \\ \text { CD1d } & \text { Cluster of differentiation 1 } \\ \text { CD44 } & \text { Cluster of differentiation } 44 \\ \text { DR } & \text { Death receptor } \\ \text { Gli 1 } & \text { Glioma-associated oncogene 1 } \\ \text { GSH } & \text { Glutathione } \\ \text { IL-6 } & \text { Interleukin } 6 \\ \text { IL-8 } & \text { Interleukin } 8 \\ \text { IL-1 } \beta & \text { Interleukin 1 beta } \\ \text { JAK2 } & \text { Janus kinase 2 } \\ \text { MMP-3 } & \text { matrix metalloproteinase-3 } \\ \text { MMP-9 } & \text { Matrix metallopeptidase } 9 \\ \text { mTOR } & \text { Mammalian target of rapamycin } \\ \text { NF- } B & \text { nuclear factor kappa light chain enhancer of activated B cells } \\ \text { OSCC } & \text { Oral squamous cell carcinoma } \\ \text { ROCK } & \text { Rho-associated protein kinase } \\ \text { ROS } & \text { Reactive oxygen species } \\ \text { STAT-3 } & \text { Signal transducer and activator of transcription } 3 \\ \text { TGF- } \beta 1 & \text { Transforming growth factor beta 1 } \\ \text { TNF } \alpha & \text { Tumour necrosis factor alpha } \\ \text { VEGF } & \text { Vascular endothelial growth factor } \\ & \end{array}$

\section{References}

1. Husain, I.; Ahmad, R.; Chandra, A.; Raza, S.T.; Shukla, Y.; Mahdi, F. Phytochemical characterization and biological activity evaluation of ethanolic extract of Cinnamomum zeylanicum. J. Ethnopharmacol. 2018, 219, 110-116. [CrossRef] [PubMed]

2. Khwairakpam, A.D.; Bordoloi, D.; Thakur, K.K.; Monisha, J.; Arfuso, F.; Sethi, G.; Mishra, S.; Kumar, A.P.; Kunnumakkara, A.B. Possible use of Punica granatum (Pomegranate) in cancer therapy. Pharmacol. Res. 2018, 133, 53-64. [CrossRef] [PubMed]

3. Sithara, T.; Dhanya, B.P.; Arun, K.B.; Sini, S.; Dan, M.; Kokkuvayil Vasu, R.; Nisha, P. Zerumbone, a Cyclic Sesquiterpene from Zingiber zerumbet Induces Apoptosis, Cell Cycle Arrest, and Antimigratory Effects in SW480 Colorectal Cancer Cells. J. Agric. Food Chem. 2018, 66, 602-612. [CrossRef] [PubMed]

4. Siegel, R.L.; Miller, K.D.; Jemal, A. Cancer statistics, 2018. CA Cancer J. Clin. 2018, 68, 7-30. [CrossRef]

5. Ranaware, A.M.; Banik, K.; Deshpande, V.; Padmavathi, G.; Roy, N.K.; Sethi, G.; Fan, L.; Kumar, A.P.; Kunnumakkara, A.B. Magnolol: A Neolignan from the Magnolia Family for the Prevention and Treatment of Cancer. Int. J. Mol. Sci. 2018, 19, 2362. [CrossRef] [PubMed]

6. Weiderpass, E. Lifestyle and cancer risk. J. Prev. Med. Public Health=Yebang Uihakhoe Chi 2010, 43, 459-471. [CrossRef] [PubMed] 
7. Kunnumakkara, A.B.; Nair, A.S.; Ahn, K.S.; Pandey, M.K.; Yi, Z.; Liu, M.; Aggarwal, B.B. Gossypin, a pentahydroxy glucosyl flavone, inhibits the transforming growth factor $\beta$-activated kinase-1-mediated NF- $\mathrm{BB}$ activation pathway, leading to potentiation of apoptosis, suppression of invasion, and abrogation of osteoclastogenesis. Blood 2007, 109, 5112-5121, Erratum in 2013, 122, 1327-1328. [CrossRef]

8. Saranya, J.; Dhanya, B.P.; Greeshma, G.; Radhakrishnan, K.V.; Priya, S. Effects of a new synthetic zerumbone pendant derivative (ZPD) on apoptosis induction and anti-migratory effects in human cervical cancer cells. Chem. Biol. Interact. 2017, 278, 32-39. [CrossRef] [PubMed]

9. Roy, N.K.; Deka, A.; Bordoloi, D.; Mishra, S.; Kumar, A.P.; Sethi, G.; Kunnumakkara, A.B. The potential role of boswellic acids in cancer prevention and treatment. Cancer Lett. 2016, 377, 74-86. [CrossRef] [PubMed]

10. Monisha, J.; Padmavathi, G.; Roy, N.K.; Deka, A.; Bordoloi, D.; Anip, A.; Kunnumakkara, A.B. NF-кB Blockers Gifted by Mother Nature: Prospectives in Cancer Cell Chemosensitization. Curr. Pharm. Des. 2016, 22, 4173-4200. [CrossRef] [PubMed]

11. Banik, K.; Harsha, C.; Bordoloi, D.; Lalduhsaki Sailo, B.; Sethi, G.; Leong, H.C.; Arfuso, F.; Mishra, S.; Wang, L.; Kumar, A.P.; et al. Therapeutic potential of gambogic acid, a caged xanthone, to target cancer. Cancer Lett. 2018, 416, 75-86. [CrossRef] [PubMed]

12. Monisha, J.; Roy, N.K.; Padmavathi, G.; Banik, K.; Bordoloi, D.; Khwairakpam, A.D.; Arfuso, F.; Chinnathambi, A.; Alahmadi, T.A.; Alharbi, S.A.; et al. NGAL is Downregulated in Oral Squamous Cell Carcinoma and Leads to Increased Survival, Proliferation, Migration and Chemoresistance. Cancers 2018, 10, 228. [CrossRef] [PubMed]

13. Wang, D.; Li, Y.; Cui, P.; Zhao, Q.; Tan, B.B.; Zhang, Z.D.; Liu, Y.; Jia, N. Zerumbone induces gastric cancer cells apoptosis: Involving cyclophilin A. Biomed. Pharmacother. = Biomed. Pharmacother. 2016, 83, 740-745. [CrossRef]

14. Aggarwal, B.B.; Kunnumakkara, A.B.; Harikumar, K.B.; Tharakan, S.T.; Sung, B.; Anand, P. Potential of spice-derived phytochemicals for cancer prevention. Planta Med. 2008, 74, 1560-1569. [CrossRef] [PubMed]

15. Sung, B.; Prasad, S.; Yadav, V.R.; Aggarwal, B.B. Cancer cell signaling pathways targeted by spice-derived nutraceuticals. Nutr. Cancer 2012, 64, 173-197. [CrossRef] [PubMed]

16. Hemn, H.O.; Hazilawati, H.; Noordin, M.M.; Heshu, S.R.; Zuki, A. Influence of Zerumbone Supplementation a Natural Dietary Product from Zingiber zerumbet smith on Early-Developed Atherosclerotic Lesions in Cholesterol-Fed Rabbits. Open Conf. Proc. J. 2013, 4, 61-64. [CrossRef]

17. Ghasemzadeh, A.; Jaafar, H.Z.; Rahmat, A.; Swamy, M.K. Optimization of microwave-assisted extraction of zerumbone from Zingiber zerumbet L. rhizome and evaluation of antiproliferative activity of optimized extracts. Chem. Cent. J. 2017, 11, 5. [CrossRef] [PubMed]

18. Sailo, B.L.; Banik, K.; Padmavathi, G.; Javadi, M.; Bordoloi, D.; Kunnumakkara, A.B. Tocotrienols: The promising analogues of vitamin E for cancer therapeutics. Pharmacol. Res. 2018, 130, 259-272. [CrossRef]

19. Deorukhkar, A.; Krishnan, S.; Sethi, G.; Aggarwal, B.B. Back to basics: How natural products can provide the basis for new therapeutics. Expert Opin. Investig. Drugs 2007, 16, 1753-1773. [CrossRef]

20. Yang, S.F.; Weng, C.J.; Sethi, G.; Hu, D.N. Natural bioactives and phytochemicals serve in cancer treatment and prevention. Evid. Based Complement. Altern. Med. 2013, 2013, 698190. [CrossRef]

21. Tang, C.H.; Sethi, G.; Kuo, P.L. Novel medicines and strategies in cancer treatment and prevention. BioMed Res. Int. 2014, 2014, 474078. [CrossRef]

22. Hsieh, Y.S.; Yang, S.F.; Sethi, G.; Hu, D.N. Natural bioactives in cancer treatment and prevention. BioMed Res. Int. 2015, 2015, 182835. [CrossRef] [PubMed]

23. Yarla, N.S.; Bishayee, A.; Sethi, G.; Reddanna, P.; Kalle, A.M.; Dhananjaya, B.L.; Dowluru, K.S.; Chintala, R.; Duddukuri, G.R. Targeting arachidonic acid pathway by natural products for cancer prevention and therapy. Semin. Cancer Biol. 2016, 40-41, 48-81. [CrossRef] [PubMed]

24. Hasanpourghadi, M.; Looi, C.Y.; Pandurangan, A.K.; Sethi, G.; Wong, W.F.; Mustafa, M.R. Phytometabolites Targeting the Warburg Effect in Cancer Cells: A Mechanistic Review. Curr. Drug Targets 2017, 18, 1086-1094. [CrossRef] [PubMed]

25. Shanmugam, M.K.; Warrier, S.; Kumar, A.P.; Sethi, G.; Arfuso, F. Potential Role of Natural Compounds as Anti-Angiogenic Agents in Cancer. Curr. Vasc. Pharmacol. 2017, 15, 503-519. [CrossRef] [PubMed]

26. Kunnumakkara, A.B.; Sailo, B.L.; Banik, K.; Harsha, C.; Prasad, S.; Gupta, S.C.; Bharti, A.C.; Aggarwal, B.B. Chronic diseases, inflammation, and spices: How are they linked? J. Transl. Med. 2018, 16, 14. [CrossRef] [PubMed] 
27. Tewari, D.; Nabavi, S.F.; Nabavi, S.M.; Sureda, A.; Farooqi, A.A.; Atanasov, A.G.; Vacca, R.A.; Sethi, G.; Bishayee, A. Targeting activator protein 1 signaling pathway by bioactive natural agents: Possible therapeutic strategy for cancer prevention and intervention. Pharmacol. Res. 2018, 128, 366-375. [CrossRef] [PubMed]

28. Kunnumakkara, A.B.; Bordoloi, D.; Harsha, C.; Banik, K.; Gupta, S.C.; Aggarwal, B.B. Curcumin mediates anticancer effects by modulating multiple cell signaling pathways. Clin. Sci. 2017, 131, 1781-1799. [CrossRef]

29. Kashyap, D.; Sharma, A.; Tuli, H.S.; Sak, K.; Garg, V.K.; Buttar, H.S.; Setzer, W.N.; Sethi, G. Apigenin: A natural bioactive flavone-type molecule with promising therapeutic function. J. Funct. Foods 2018, 48, 457-471. [CrossRef]

30. Zakaria, Z.A.; Mohamad, A.S.; Chear, C.T.; Wong, Y.Y.; Israf, D.A.; Sulaiman, M.R. Antiinflammatory and antinociceptive activities of Zingiber zerumbet methanol extract in experimental model systems. Med Princ. Pract. 2010, 19, 287-294. [CrossRef]

31. Rajan, I.; Rabindran, R.; Nithya, N.; Lakshmipriya, T.; Jayasree, P.R.; Kumar, P.R. Assessment of cell cycle phase-specific effects of zerumbone on mitotically synchronous surface cultures of Physarum polycephalum. Protoplasma 2014, 251, 931-941. [CrossRef] [PubMed]

32. Wang, L.; Phan, D.D.; Zhang, J.; Ong, P.S.; Thuya, W.L.; Soo, R.; Wong, A.L.; Yong, W.P.; Lee, S.C.; Ho, P.C.; et al. Anticancer properties of nimbolide and pharmacokinetic considerations to accelerate its development. Oncotarget 2016, 7, 44790-44802. [CrossRef] [PubMed]

33. Tan, J.W.; Israf, D.A.; Tham, C.L. Major Bioactive Compounds in Essential Oils Extracted From the Rhizomes of Zingiber zerumbet (L) Smith: A Mini-Review on the Anti-allergic and Immunomodulatory Properties. Front. Pharmacol. 2018, 9, 652. [CrossRef] [PubMed]

34. Prasannan, R.; Kalesh, K.A.; Shanmugam, M.K.; Nachiyappan, A.; Ramachandran, L.; Nguyen, A.H.; Kumar, A.P.; Lakshmanan, M.; Ahn, K.S.; Sethi, G. Key cell signaling pathways modulated by zerumbone: Role in the prevention and treatment of cancer. Biochem. Pharmacol. 2012, 84, 1268-1276. [CrossRef] [PubMed]

35. Kitayama, T. Attractive reactivity of a natural product, zerumbone. Biosci. Biotechnol. Biochem. 2011, 75, 199-207. [CrossRef] [PubMed]

36. Gupta, S.C.; Kim, J.H.; Prasad, S.; Aggarwal, B.B. Regulation of survival, proliferation, invasion, angiogenesis, and metastasis of tumor cells through modulation of inflammatory pathways by nutraceuticals. Cancer Metastasis Rev. 2010, 29, 405-434. [CrossRef] [PubMed]

37. Haque, M.A.; Jantan, I.; Arshad, L.; Bukhari, S.N.A. Exploring the immunomodulatory and anticancer properties of zerumbone. Food Funct. 2017, 8, 3410-3431. [CrossRef] [PubMed]

38. Kang, C.G.; Lee, H.J.; Kim, S.H.; Lee, E.O. Zerumbone Suppresses Osteopontin-Induced Cell Invasion Through Inhibiting the FAK/AKT/ROCK Pathway in Human Non-Small Cell Lung Cancer A549 Cells. J. Nat. Prod. 2016, 79, 156-160. [CrossRef] [PubMed]

39. Fusi, F.; Durante, M.; Sgaragli, G.; Khanh, P.N.; Son, N.T.; Huong, T.T.; Huong, V.N.; Cuong, N.M. In vitro vasoactivity of zerumbone from Zingiber zerumbet. Planta Med. 2015, 81, 298-304. [CrossRef] [PubMed]

40. Singh, S.P.; Nongalleima, K.; Singh, N.I.; Doley, P.; Singh, C.B.; Singh, T.R.; Sahoo, D. Zerumbone reduces proliferation of HCT116 colon cancer cells by inhibition of TNF-alpha. Sci. Rep. 2018, 8, 4090. [CrossRef]

41. Rahman, H.S.; Rasedee, A.; How, C.W.; Abdul, A.B.; Zeenathul, N.A.; Othman, H.H.; Saeed, M.I.; Yeap, S.K. Zerumbone-loaded nanostructured lipid carriers: Preparation, characterization, and antileukemic effect. Int. J. Nanomed. 2013, 8, 2769-2781. [CrossRef] [PubMed]

42. Rahman, H.S.; Rasedee, A.; Yeap, S.K.; Othman, H.H.; Chartrand, M.S.; Namvar, F.; Abdul, A.B.; How, C.W. Biomedical properties of a natural dietary plant metabolite, zerumbone, in cancer therapy and chemoprevention trials. BioMed Res. Int. 2014, 2014, 920742. [CrossRef] [PubMed]

43. Chan, M.L.; Liang, J.W.; Hsu, L.C.; Chang, W.L.; Lee, S.S.; Guh, J.H. Zerumbone, a ginger sesquiterpene, induces apoptosis and autophagy in human hormone-refractory prostate cancers through tubulin binding and crosstalk between endoplasmic reticulum stress and mitochondrial insult. Naunyn-Schmiedeberg's Arch. Pharmacol. 2015, 388, 1223-1236. [CrossRef] [PubMed]

44. Singh, Y.P.; Girisa, S.; Banik, K.; Ghosh, S.; Swathi, P.; Deka, M.; Padmavathi, G.; Kotoky, J.; Sethi, G.; Fan, L.; et al. Potential application of zerumbone in the prevention and therapy of chronic human diseases. J. Funct. Foods 2019, 53, 248-258. [CrossRef]

45. Kirana, C.; McIntosh, G.H.; Record, I.R.; Jones, G.P. Antitumor activity of extract of Zingiber aromaticum and its bioactive sesquiterpenoid zerumbone. Nutr. Cancer 2003, 45, 218-225. [CrossRef] 
46. Kalantari, K.; Moniri, M.; Boroumand Moghaddam, A.; Abdul Rahim, R.; Bin Ariff, A.; Izadiyan, Z.; Mohamad, R. A Review of the Biomedical Applications of Zerumbone and the Techniques for Its Extraction from Ginger Rhizomes. Molecules 2017, 22, 1645. [CrossRef]

47. Leung, W.S.; Yang, M.L.; Lee, S.S.; Kuo, C.W.; Ho, Y.C.; Huang-Liu, R.; Lin, H.W.; Kuan, Y.H. Protective effect of zerumbone reduces lipopolysaccharide-induced acute lung injury via antioxidative enzymes and Nrf2/HO-1 pathway. Int. Immunopharmacol. 2017, 46, 194-200. [CrossRef]

48. Nakamura, Y.; Yoshida, C.; Murakami, A.; Ohigashi, H.; Osawa, T.; Uchida, K. Zerumbone, a tropical ginger sesquiterpene, activates phase II drug metabolizing enzymes. FEBS Lett. 2004, 572, 245-250. [CrossRef]

49. Songsiang, U.; Pitchuanchom, S.; Boonyarat, C.; Hahnvajanawong, C.; Yenjai, C. Cytotoxicity against cholangiocarcinoma cell lines of zerumbone derivatives. Eur. J. Med. Chem. 2010, 45, 3794-3802. [CrossRef]

50. Eid, E.E.M.; Abdul, A.B.; Suliman, F.E.O.; Sukari, M.A.; Rasedee, A.; Fatah, S.S. Characterization of the inclusion complex of zerumbone with hydroxypropyl- $\beta$-cyclodextrin. Carbohydr. Polym. 2011, 83, 1707-1714. [CrossRef]

51. Kalesh, K.A.; Clulow, J.A.; Tate, E.W. Target profiling of zerumbone using a novel cell-permeable clickable probe and quantitative chemical proteomics. Chem. Commun. 2015, 51, 5497-5500. [CrossRef] [PubMed]

52. Shanmugam, M.K.; Kannaiyan, R.; Sethi, G. Targeting cell signaling and apoptotic pathways by dietary agents: Role in the prevention and treatment of cancer. Nutr. Cancer 2011, 63, 161-173. [CrossRef] [PubMed]

53. Aggarwal, B.B.; Sethi, G.; Baladandayuthapani, V.; Krishnan, S.; Shishodia, S. Targeting cell signaling pathways for drug discovery: An old lock needs a new key. J. Cell. Biochem. 2007, 102, 580-592. [CrossRef] [PubMed]

54. Parikh, N.R.; Mandal, A.; Bhatia, D.; Siveen, K.S.; Sethi, G.; Bishayee, A. Oleanane triterpenoids in the prevention and therapy of breast cancer: Current evidence and future perspectives. Phytochem. Rev. Proc. Phytochem. Soc. Eur. 2014, 13, 793-810. [CrossRef] [PubMed]

55. Kanchi, M.M.; Shanmugam, M.K.; Rane, G.; Sethi, G.; Kumar, A.P. Tocotrienols: The unsaturated sidekick shifting new paradigms in vitamin E therapeutics. Drug Discov. Today 2017, 22, 1765-1781. [CrossRef]

56. Ko, J.H.; Sethi, G.; Um, J.Y.; Shanmugam, M.K.; Arfuso, F.; Kumar, A.P.; Bishayee, A.; Ahn, K.S. The Role of Resveratrol in Cancer Therapy. Int. J. Mol. Sci. 2017, 18, 2589. [CrossRef]

57. Shanmugam, M.K.; Arfuso, F.; Kumar, A.P.; Wang, L.; Goh, B.C.; Ahn, K.S.; Bishayee, A.; Sethi, G. Modulation of diverse oncogenic transcription factors by thymoquinone, an essential oil compound isolated from the seeds of Nigella sativa Linn. Pharmacol. Res. 2018, 129, 357-364. [CrossRef]

58. Sethi, G.; Shanmugam, M.K.; Warrier, S.; Merarchi, M.; Arfuso, F.; Kumar, A.P.; Bishayee, A. Pro-Apoptotic and Anti-Cancer Properties of Diosgenin: A Comprehensive and Critical Review. Nutrients 2018, 10, 645. [CrossRef] [PubMed]

59. Wang, S.D.; Wang, Z.H.; Yan, H.Q.; Ren, M.Y.; Gao, S.Q.; Zhang, G.Q. Chemotherapeutic effect of Zerumbone on melanoma cells through mitochondria-mediated pathways. Clin. Exp. Dermatol. 2016, 41, 858-863. [CrossRef]

60. Sehrawat, A.; Arlotti, J.A.; Murakami, A.; Singh, S.V. Zerumbone causes Bax- and Bak-mediated apoptosis in human breast cancer cells and inhibits orthotopic xenograft growth in vivo. Breast Cancer Res. Treat. 2012, 136, 429-441. [CrossRef]

61. Sung, B.; Jhurani, S.; Ahn, K.S.; Mastuo, Y.; Yi, T.; Guha, S.; Liu, M.; Aggarwal, B.B. Zerumbone down-regulates chemokine receptor CXCR4 expression leading to inhibition of CXCL12-induced invasion of breast and pancreatic tumor cells. Cancer Res. 2008, 68, 8938-8944. [CrossRef] [PubMed]

62. Weng, H.Y.; Hsu, M.J.; Wang, C.C.; Chen, B.C.; Hong, C.Y.; Chen, M.C.; Chiu, W.T.; Lin, C.H. Zerumbone suppresses IKKalpha, Akt, and FOXO1 activation, resulting in apoptosis of GBM 8401 cells. J. Biomed. Sci. 2012, 19, 86. [CrossRef]

63. Shin, J.W.; Ohnishi, K.; Murakami, A.; Lee, J.S.; Kundu, J.K.; Na, H.K.; Ohigashi, H.; Surh, Y.J. Zerumbone induces heme oxygenase-1 expression in mouse skin and cultured murine epidermal cells through activation of Nrf2. Cancer Prev. Res. 2011, 4, 860-870. [CrossRef] [PubMed]

64. Sung, B.; Murakami, A.; Oyajobi, B.O.; Aggarwal, B.B. Zerumbone abolishes RANKL-induced NF-кB activation, inhibits osteoclastogenesis, and suppresses human breast cancer-induced bone loss in athymic nude mice. Cancer Res. 2009, 69, 1477-1484. [CrossRef] 
65. Xian, M.; Ito, K.; Nakazato, T.; Shimizu, T.; Chen, C.K.; Yamato, K.; Murakami, A.; Ohigashi, H.; Ikeda, Y.; Kizaki, M. Zerumbone, a bioactive sesquiterpene, induces G2/M cell cycle arrest and apoptosis in leukemia cells via a Fas- and mitochondria-mediated pathway. Cancer Sci. 2007, 98, 118-126. [CrossRef]

66. Matsuo, Y.; Takeyama, H. Zerumbone from Ginger (Monoterpenoid). Enzymes 2014, 36, 87-94. [CrossRef] [PubMed]

67. Taha, M.M.; Abdul, A.B.; Abdullah, R.; Ibrahim, T.A.; Abdelwahab, S.I.; Mohan, S. Potential chemoprevention of diethylnitrosamine-initiated and 2-acetylaminofluorene-promoted hepatocarcinogenesis by zerumbone from the rhizomes of the subtropical ginger (Zingiber zerumbet). Chem. Biol. Interact. 2010, 186, 295-305. [CrossRef] [PubMed]

68. Bousselham, A.; Bouattane, O.; Youssfi, M.; Raihani, A. Brain tumor temperature effect extraction from MRI imaging using bioheat equation. Procedia Comput. Sci. 2018, 127, 336-343. [CrossRef]

69. Guerreiro Stucklin, A.S.; Ramaswamy, V.; Daniels, C.; Taylor, M.D. Review of molecular classification and treatment implications of pediatric brain tumors. Curr. Opin. Pediatr. 2018, 30, 3-9. [CrossRef] [PubMed]

70. Kansal, A.R.; Torquato, S.; Harsh, G.I.; Chiocca, E.A.; Deisboeck, T.S. Simulated brain tumor growth dynamics using a three-dimensional cellular automaton. J. Theor. Biol. 2000, 203, 367-382. [CrossRef] [PubMed]

71. Kim, S.; Kil, W.H.; Lee, J.; Oh, S.J.; Han, J.; Jeon, M.; Jung, T.; Lee, S.K.; Bae, S.Y.; Lee, H.C.; et al. Zerumbone suppresses EGF-induced CD44 expression through the inhibition of STAT3 in breast cancer cells. Oncol. Rep. 2014, 32, 2666-2672. [CrossRef] [PubMed]

72. Jeon, M.; Han, J.; Nam, S.J.; Lee, J.E.; Kim, S. Elevated IL-1 $\beta$ expression induces invasiveness of triple negative breast cancer cells and is suppressed by zerumbone. Chem. Biol. Interact. 2016, 258, 126-133. [CrossRef] [PubMed]

73. Wang, C.; Kar, S.; Lai, X.; Cai, W.; Arfuso, F.; Sethi, G.; Lobie, P.E.; Goh, B.C.; Lim, L.H.K.; Hartman, M.; et al. Triple negative breast cancer in Asia: An insider's view. Cancer Treat. Rev. 2018, 62, 29-38. [CrossRef] [PubMed]

74. Jia, L.Y.; Shanmugam, M.K.; Sethi, G.; Bishayee, A. Potential role of targeted therapies in the treatment of triple-negative breast cancer. Anti-Cancer Drugs 2016, 27, 147-155. [CrossRef] [PubMed]

75. Bhuvanalakshmi, G.; Basappa; Rangappa, K.S.; Dharmarajan, A.; Sethi, G.; Kumar, A.P.; Warrier, S. Breast Cancer Stem-Like Cells Are Inhibited by Diosgenin, a Steroidal Saponin, by the Attenuation of the Wnt $\beta$-Catenin Signaling via the Wnt Antagonist Secreted Frizzled Related Protein-4. Front. Pharmacol. 2017, 8 , 124. [CrossRef] [PubMed]

76. Yuan, Y.; Anbalagan, D.; Lee, L.H.; Samy, R.P.; Shanmugam, M.K.; Kumar, A.P.; Sethi, G.; Lobie, P.E.; Lim, L.H. ANXA1 inhibits miRNA-196a in a negative feedback loop through NF-kB and c-Myc to reduce breast cancer proliferation. Oncotarget 2016, 7, 27007-27020. [CrossRef] [PubMed]

77. Kim, S.; Lee, J.; Jeon, M.; Lee, J.E.; Nam, S.J. Zerumbone suppresses the motility and tumorigenecity of triple negative breast cancer cells via the inhibition of TGF- $\beta 1$ signaling pathway. Oncotarget 2016, 7, 1544-1558. [CrossRef] [PubMed]

78. Thakur, K.K.; Bordoloi, D.; Kunnumakkara, A.B. Alarming Burden of Triple-Negative Breast Cancer in India. Clin. Breast Cancer 2018, 18, e393-e399. [CrossRef]

79. Sehrawat, A.; Sakao, K.; Singh, S.V. Notch2 activation is protective against anticancer effects of zerumbone in human breast cancer cells. Breast Cancer Res. Treat. 2014, 146, 543-555. [CrossRef] [PubMed]

80. Han, J.; Bae, S.Y.; Oh, S.J.; Lee, J.; Lee, J.H.; Lee, H.C.; Lee, S.K.; Kil, W.H.; Kim, S.W.; Nam, S.J.; et al. Zerumbone suppresses IL-1 $\beta$-induced cell migration and invasion by inhibiting IL-8 and MMP-3 expression in human triple-negative breast cancer cells. Phytother. Res. 2014, 28, 1654-1660. [CrossRef] [PubMed]

81. Aggarwal, B.; Prasad, S.; Sung, B.; Krishnan, S.; Guha, S. Prevention and Treatment of Colorectal Cancer by Natural Agents From Mother Nature. Curr. Colorectal Cancer Rep. 2013, 9, 37-56. [CrossRef] [PubMed]

82. Deorukhkar, A.; Ahuja, N.; Mercado, A.L.; Diagaradjane, P.; Raju, U.; Patel, N.; Mohindra, P.; Diep, N.; Guha, S.; Krishnan, S. Zerumbone increases oxidative stress in a thiol-dependent ROS-independent manner to increase DNA damage and sensitize colorectal cancer cells to radiation. Cancer Med. 2015, 4, 278-292. [CrossRef] [PubMed] 
83. Murakami, A.; Takahashi, D.; Kinoshita, T.; Koshimizu, K.; Kim, H.W.; Yoshihiro, A.; Nakamura, Y.; Jiwajinda, S.; Terao, J.; Ohigashi, H. Zerumbone, a Southeast Asian ginger sesquiterpene, markedly suppresses free radical generation, proinflammatory protein production, and cancer cell proliferation accompanied by apoptosis: The alpha, $\beta$-unsaturated carbonyl group is a prerequisite. Carcinogenesis 2002, 23, 795-802. [CrossRef]

84. Yodkeeree, S.; Sung, B.; Limtrakul, P.; Aggarwal, B.B. Zerumbone enhances TRAIL-induced apoptosis through the induction of death receptors in human colon cancer cells: Evidence for an essential role of reactive oxygen species. Cancer Res. 2009, 69, 6581-6589. [CrossRef]

85. Murakami, A.; Miyamoto, M.; Ohigashi, H. Zerumbone, an anti-inflammatory phytochemical, induces expression of proinflammatory cytokine genes in human colon adenocarcinoma cell lines. Biofactors 2004, 21, 95-101. [CrossRef]

86. Hosseini, N.; Khoshnazar, A.; Saidijam, M.; Azizi Jalilian, F.; Najafi, R.; Mahdavinezhad, A.; Ezati, R.; Sotanian, A.; Amini, R. Zerumbone Suppresses Human Colorectal Cancer Invasion and Metastasis via Modulation of FAk/PI3k/NFkB-uPA Pathway. Nutr. Cancer 2019, 1-13. [CrossRef] [PubMed]

87. Kim, M.; Miyamoto, S.; Yasui, Y.; Oyama, T.; Murakami, A.; Tanaka, T. Zerumbone, a tropical ginger sesquiterpene, inhibits colon and lung carcinogenesis in mice. Int. J. Cancer 2009, 124, 264-271. [CrossRef] [PubMed]

88. Farooq, M.; Egan, J.B.; McDonald, B.; Markus, H.; Contente-Cuomo, T.; Fernandez-Zapico, M.; Vasmatzis, G.; Braggio, E.; Borad, M.J.; Murtaza, M. Detection of copy number aberrations in cholangiocarcinoma using shallow whole genome sequencing of plasma DNA. J. Clin. Oncol. 2018, 36 (Suppl. 4), 293. [CrossRef]

89. Kitdumrongthum, S.; Metheetrairut, C.; Charoensawan, V.; Ounjai, P.; Janpipatkul, K.; Panvongsa, W.; Weerachayaphorn, J.; Piyachaturawat, P.; Chairoungdua, A. Dysregulated microRNA expression profiles in cholangiocarcinoma cell-derived exosomes. Life Sci. 2018, 210, 65-75. [CrossRef] [PubMed]

90. Xu, Y.; Yao, Y.; Zhong, X.; Leng, K.; Qin, W.; Qu, L.; Cui, Y.; Jiang, X. Downregulated circular RNA hsa_circ_0001649 regulates proliferation, migration and invasion in cholangiocarcinoma cells. Biochem. Biophys. Res. Commun. 2018, 496, 455-461. [CrossRef] [PubMed]

91. Shaib, Y.; El-Serag, H.B. The epidemiology of cholangiocarcinoma. Semin. Liver Dis. 2004, 24, 115-125. [CrossRef] [PubMed]

92. Bozko, P.; Scholta, T.; Bui, K.; Toulany, M.; Rodemann, H.; Malek, N. Notch1-Cyclin E-p27kip1 and RAD17 form a network of proteins which control cellular proliferation and DNA damage response in cholangiocarcinoma. Z. Gastroenterol. 2018, 56, A4.81. [CrossRef]

93. Qin, W.; Kang, P.; Xu, Y.; Leng, K.; Li, Z.; Huang, L.; Gao, J.; Cui, Y.; Zhong, X. Long non-coding RNA HOTAIR promotes tumorigenesis and forecasts a poor prognosis in cholangiocarcinoma. Sci. Rep. 2018, 8, 12176. [CrossRef] [PubMed]

94. Li, L.Q.; Pan, D.; Zhang, S.W.; Xie, D.; Zheng, X.L.; Chen, H. Autophagy regulates chemoresistance of gastric cancer stem cells via the Notch signaling pathway. Eur. Rev. Med. Pharmacol. Sci. 2018, 22, 3402-3407. [CrossRef] [PubMed]

95. Manu, K.A.; Shanmugam, M.K.; Ramachandran, L.; Li, F.; Fong, C.W.; Kumar, A.P.; Tan, P.; Sethi, G. First evidence that gamma-tocotrienol inhibits the growth of human gastric cancer and chemosensitizes it to capecitabine in a xenograft mouse model through the modulation of NF-кB pathway. Clin. Cancer Res. 2012, 18, 2220-2229. [CrossRef] [PubMed]

96. Manu, K.A.; Shanmugam, M.K.; Li, F.; Chen, L.; Siveen, K.S.; Ahn, K.S.; Kumar, A.P.; Sethi, G. Simvastatin sensitizes human gastric cancer xenograft in nude mice to capecitabine by suppressing nuclear factor-kappa B-regulated gene products. J. Mol. Med. 2014, 92, 267-276. [CrossRef]

97. Manu, K.A.; Shanmugam, M.K.; Ramachandran, L.; Li, F.; Siveen, K.S.; Chinnathambi, A.; Zayed, M.E.; Alharbi, S.A.; Arfuso, F.; Kumar, A.P.; et al. Isorhamnetin augments the anti-tumor effect of capeciatbine through the negative regulation of NF-kB signaling cascade in gastric cancer. Cancer Lett. 2015, 363, $28-36$. [CrossRef] [PubMed]

98. Ramachandran, L.; Manu, K.A.; Shanmugam, M.K.; Li, F.; Siveen, K.S.; Vali, S.; Kapoor, S.; Abbasi, T.; Surana, R.; Smoot, D.T.; et al. Isorhamnetin inhibits proliferation and invasion and induces apoptosis through the modulation of peroxisome proliferator-activated receptor gamma activation pathway in gastric cancer. J. Biol. Chem. 2012, 287, 38028-38040. [CrossRef] [PubMed] 
99. Tsuboi, K.; Matsuo, Y.; Shamoto, T.; Shibata, T.; Koide, S.; Morimoto, M.; Guha, S.; Sung, B.; Aggarwal, B.B.; Takahashi, H.; et al. Zerumbone inhibits tumor angiogenesis via NF-kB in gastric cancer. Oncol. Rep. 2014, 31, 57-64. [CrossRef]

100. Abdelwahab, S.I.; Abdul, A.B.; Mohan, S.; Taha, M.M.; Syam, S.; Ibrahim, M.Y.; Mariod, A.A. Zerumbone induces apoptosis in T-acute lymphoblastic leukemia cells. Leuk. Res. 2011, 35, 268-271. [CrossRef] [PubMed]

101. Huang, G.C.; Chien, T.Y.; Chen, L.G.; Wang, C.C. Antitumor effects of zerumbone from Zingiber zerumbet in P-388D1 cells in vitro and in vivo. Planta Med. 2005, 71, 219-224. [CrossRef] [PubMed]

102. Rahman, H.S.; Rasedee, A.; Abdul, A.B.; Zeenathul, N.A.; Othman, H.H.; Yeap, S.K.; How, C.W.; Hafiza, W.A. Zerumbone-loaded nanostructured lipid carrier induces G2/M cell cycle arrest and apoptosis via mitochondrial pathway in a human lymphoblastic leukemia cell line. Int. J. Nanomed. 2014, 9, 527-538. [CrossRef]

103. Rahman, H.S.; Rasedee, A.; Chartrand, M.S.; Othman, H.H.; Yeap, S.K.; Namvar, F. Zerumbone induces $\mathrm{G} 2 / \mathrm{M}$ cell cycle arrest and apoptosis via mitochondrial pathway in Jurkat cell line. Nat. Prod. Commun. 2014, 9, 1237-1242. [PubMed]

104. Rahman, H.S.; Rasedee, A.; How, C.W.; Zeenathul, N.A.; Chartrand, M.S.; Yeap, S.K.; Abdul, A.B.; Tan, S.W.; Othman, H.H.; Ajdari, Z.; et al. Antileukemic effect of zerumbone-loaded nanostructured lipid carrier in WEHI-3B cell-induced murine leukemia model. Int. J. Nanomed. 2015, 10, 1649-1666. [CrossRef] [PubMed]

105. Rajan, I.; Jayasree, P.R.; Kumar, P.R. Zerumbone induces mitochondria-mediated apoptosis via increased calcium, generation of reactive oxygen species and upregulation of soluble histone H2AX in K562 chronic myelogenous leukemia cells. Tumour Biol. 2015, 36, 8479-8489. [CrossRef] [PubMed]

106. Sethi, G.; Chatterjee, S.; Rajendran, P.; Li, F.; Shanmugam, M.K.; Wong, K.F.; Kumar, A.P.; Senapati, P.; Behera, A.K.; Hui, K.M.; et al. Inhibition of STAT3 dimerization and acetylation by garcinol suppresses the growth of human hepatocellular carcinoma in vitro and in vivo. Mol. Cancer 2014, 13, 66. [CrossRef] [PubMed]

107. Siveen, K.S.; Ahn, K.S.; Ong, T.H.; Shanmugam, M.K.; Li, F.; Yap, W.N.; Kumar, A.P.; Fong, C.W.; Tergaonkar, V.; Hui, K.M.; et al. Y-tocotrienol inhibits angiogenesis-dependent growth of human hepatocellular carcinoma through abrogation of AKT/mTOR pathway in an orthotopic mouse model. Oncotarget 2014, 5, 1897-1911. [CrossRef] [PubMed]

108. Swamy, S.G.; Kameshwar, V.H.; Shubha, P.B.; Looi, C.Y.; Shanmugam, M.K.; Arfuso, F.; Dharmarajan, A.; Sethi, G.; Shivananju, N.S.; Bishayee, A. Targeting multiple oncogenic pathways for the treatment of hepatocellular carcinoma. Target. Oncol. 2017, 12, 1-10. [CrossRef]

109. Dai, X.; Wang, L.; Deivasigamni, A.; Looi, C.Y.; Karthikeyan, C.; Trivedi, P.; Chinnathambi, A.; Alharbi, S.A.; Arfuso, F.; Dharmarajan, A.; et al. A novel benzimidazole derivative, MBIC inhibits tumor growth and promotes apoptosis via activation of ROS-dependent JNK signaling pathway in hepatocellular carcinoma. Oncotarget 2017, 8, 12831-12842. [CrossRef]

110. Dai, X.; Ahn, K.S.; Wang, L.Z.; Kim, C.; Deivasigamni, A.; Arfuso, F.; Um, J.Y.; Kumar, A.P.; Chang, Y.C.; Kumar, D.; et al. Ascochlorin Enhances the Sensitivity of Doxorubicin Leading to the Reversal of Epithelial-to-Mesenchymal Transition in Hepatocellular Carcinoma. Mol. Cancer Ther. 2016, 15, 2966-2976. [CrossRef]

111. Dai, X.; Ahn, K.S.; Kim, C.; Siveen, K.S.; Ong, T.H.; Shanmugam, M.K.; Li, F.; Shi, J.; Kumar, A.P.; Wang, L.Z.; et al. Ascochlorin, an isoprenoid antibiotic inhibits growth and invasion of hepatocellular carcinoma by targeting STAT3 signaling cascade through the induction of PIAS3. Mol. Oncol. 2015, 9, 818-833. [CrossRef] [PubMed]

112. Mastron, J.K.; Siveen, K.S.; Sethi, G.; Bishayee, A. Silymarin and hepatocellular carcinoma: A systematic, comprehensive, and critical review. Anti-Cancer Drugs 2015, 26, 475-486. [CrossRef] [PubMed]

113. Subramaniam, A.; Loo, S.Y.; Rajendran, P.; Manu, K.A.; Perumal, E.; Li, F.; Shanmugam, M.K.; Siveen, K.S.; Park, J.I.; Ahn, K.S.; et al. An anthraquinone derivative, emodin sensitizes hepatocellular carcinoma cells to TRAIL induced apoptosis through the induction of death receptors and downregulation of cell survival proteins. Apoptosis 2013, 18, 1175-1187. [CrossRef] [PubMed]

114. Manu, K.A.; Shanmugam, M.K.; Ong, T.H.; Subramaniam, A.; Siveen, K.S.; Perumal, E.; Samy, R.P.; Bist, P.; Lim, L.H.; Kumar, A.P.; et al. Emodin suppresses migration and invasion through the modulation of CXCR4 expression in an orthotopic model of human hepatocellular carcinoma. PLoS ONE 2013, 8, e57015. [CrossRef] [PubMed] 
115. Wani, N.A.; Zhang, B.; Teng, K.Y.; Barajas, J.M.; Motiwala, T.; Hu, P.; Yu, L.; Bruschweiler, R.; Ghoshal, K.; Jacob, S.T. Reprograming of Glucose Metabolism by Zerumbone Suppresses Hepatocarcinogenesis. Mol. Cancer Res. 2018, 16, 256-268. [CrossRef] [PubMed]

116. Samad, N.A.; Abdul, A.B.; Rahman, H.S.; Rasedee, A.; Tengku Ibrahim, T.A.; Keon, Y.S. Zerumbone Suppresses Angiogenesis in HepG2 Cells through Inhibition of Matrix Metalloproteinase-9, Vascular Endothelial Growth Factor, and Vascular Endothelial Growth Factor Receptor Expressions. Pharmacogn. Mag. 2018, 13 (Suppl. 4), S731-S736. [CrossRef]

117. Sakinah, S.A.; Handayani, S.T.; Hawariah, L.P. Zerumbone induced apoptosis in liver cancer cells via modulation of Bax/Bcl-2 ratio. Cancer Cell Int. 2007, 7, 4. [CrossRef]

118. Muhammad Nadzri, N.; Abdul, A.B.; Sukari, M.A.; Abdelwahab, S.I.; Eid, E.E.; Mohan, S.; Kamalidehghan, B.; Anasamy, T.; Ng, K.B.; Syam, S.; et al. Inclusion Complex of Zerumbone with Hydroxypropyl- $\beta$-Cyclodextrin Induces Apoptosis in Liver Hepatocellular HepG2 Cells via Caspase 8/BID Cleavage Switch and Modulating Bcl2/Bax Ratio. Evid. Based Complement. Altern. Med. 2013, 2013, 810632. [CrossRef]

119. Lee, J.H.; Kim, C.; Sethi, G.; Ahn, K.S. Brassinin inhibits STAT3 signaling pathway through modulation of PIAS-3 and SOCS-3 expression and sensitizes human lung cancer xenograft in nude mice to paclitaxel. Oncotarget 2015, 6, 6386-6405. [CrossRef]

120. Ong, P.S.; Wang, L.; Chia, D.M.; Seah, J.Y.; Kong, L.R.; Thuya, W.L.; Chinnathambi, A.; Lau, J.Y.; Wong, A.L.; Yong, W.P.; et al. A novel combinatorial strategy using Seliciclib((R)) and Belinostat((R)) for eradication of non-small cell lung cancer via apoptosis induction and BID activation. Cancer Lett. 2016, 381, 49-57. [CrossRef]

121. Wang, L.; Syn, N.L.; Subhash, V.V.; Any, Y.; Thuya, W.L.; Cheow, E.S.H.; Kong, L.; Yu, F.; Peethala, P.C.; Wong, A.L.; et al. Pan-HDAC inhibition by panobinostat mediates chemosensitization to carboplatin in non-small cell lung cancer via attenuation of EGFR signaling. Cancer Lett. 2018, 417, 152-160. [CrossRef] [PubMed]

122. Ko, J.H.; Nam, D.; Um, J.Y.; Jung, S.H.; Sethi, G.; Ahn, K.S. Bergamottin Suppresses Metastasis of Lung Cancer Cells through Abrogation of Diverse Oncogenic Signaling Cascades and Epithelial-to-Mesenchymal Transition. Molecules 2018, 23, 1601. [CrossRef]

123. Chen, Y.; Ma, Z.; Shen, X.; Li, L.; Zhong, J.; Min, L.S.; Xu, L.; Li, H.; Zhang, J.; Dai, L. Serum Lipidomics Profiling to Identify Biomarkers for Non-Small Cell Lung Cancer. BioMed Res. Int. 2018, 2018, 5276240. [CrossRef] [PubMed]

124. Pan, Z.; Liu, L.; Nie, W.; Miggin, S.; Qiu, F.; Cao, Y.; Chen, J.; Yang, B.; Zhou, Y.; Lu, J.; et al. Long non-coding RNA AGER-1 functionally upregulates the innate immunity gene AGER and approximates its anti-tumor effect in lung cancer. Mol. Carcinog. 2018, 57, 305-318. [CrossRef]

125. Hu, Z.; Zeng, Q.; Zhang, B.; Liu, H.; Wang, W. Promotion of p53 expression and reactive oxidative stress production is involved in zerumbone-induced cisplatin sensitization of non-small cell lung cancer cells. Biochimie 2014, 107 Pt B, 257-262. [CrossRef]

126. Warnakulasuriya, S. Global epidemiology of oral and oropharyngeal cancer. Oral Oncol. 2009, 45, 309-316. [CrossRef] [PubMed]

127. Khwankong, S.; Sriplung, H.; Kerdpon, D. Knowledge and Health Belief Attitudes of Oral Cancer and Its Screening Among At-Risk Southern Thai Muslims. J. Cancer Educ. 2018, 33, 615-621. [CrossRef] [PubMed]

128. Proia, N.K.; Paszkiewicz, G.M.; Nasca, M.A.; Franke, G.E.; Pauly, J.L. Smoking and smokeless tobacco-associated human buccal cell mutations and their association with oral cancer-A review. Cancer Epidemiol. Biomark. Prev. 2006, 15, 1061-1077. [CrossRef] [PubMed]

129. Zainal, N.S.; Gan, C.P.; Lau, B.F.; Yee, P.S.; Tiong, K.H.; Abdul Rahman, Z.A.; Patel, V.; Cheong, S.C. Zerumbone targets the CXCR4-RhoA and PI3K-mTOR signaling axis to reduce motility and proliferation of oral cancer cells. Phytomedicine 2018, 39, 33-41. [CrossRef] [PubMed]

130. Abdelwahab, S.I.; Abdul, A.B.; Devi, N.; Taha, M.M.; Al-zubairi, A.S.; Mohan, S.; Mariod, A.A. Regression of cervical intraepithelial neoplasia by zerumbone in female Balb/c mice prenatally exposed to diethylstilboestrol: Involvement of mitochondria-regulated apoptosis. Exp. Toxicol. Pathol. 2010, 62, 461-469. [CrossRef] 
131. Abdelwahab, S.I.; Abdul, A.B.; Zain, Z.N.; Hadi, A.H. Zerumbone inhibits interleukin-6 and induces apoptosis and cell cycle arrest in ovarian and cervical cancer cells. Int. Immunopharmacol. 2012, 12, 594-602. [CrossRef] [PubMed]

132. Abdul, A.B.; Abdelwahab, S.I.; Bin Jalinas, J.; Al-Zubairi, A.S.; Taha, M.M. Combination of zerumbone and cisplatin to treat cervical intraepithelial neoplasia in female BALB/c mice. Int. J. Gynecol. Cancer 2009, 19, 1004-1010. [CrossRef] [PubMed]

133. Abdel Wahab, S.I.; Abdul, A.B.; Alzubairi, A.S.; Mohamed Elhassan, M.; Mohan, S. In vitro ultramorphological assessment of apoptosis induced by zerumbone on (HeLa). J. Biomed. Biotechnol. 2009, 2009, 769568. [CrossRef] [PubMed]

134. Zhang, S.; Liu, Q.; Liu, Y.; Qiao, H.; Liu, Y. Zerumbone, a Southeast Asian Ginger Sesquiterpene, Induced Apoptosis of Pancreatic Carcinoma Cells through p53 Signaling Pathway. Evid. Based Complement. Altern. Med. 2012, 2012, 936030. [CrossRef] [PubMed]

135. Shamoto, T.; Matsuo, Y.; Shibata, T.; Tsuboi, K.; Nagasaki, T.; Takahashi, H.; Funahashi, H.; Okada, Y.; Takeyama, H. Zerumbone inhibits angiogenesis by blocking NF-kB activity in pancreatic cancer. Pancreas 2014, 43, 396-404. [CrossRef]

136. Lin, C.J.; Lo, U.G.; Hsieh, J.T. The regulatory pathways leading to stem-like cells underlie prostate cancer progression. Asian J. Androl. 2018. [CrossRef]

137. Zainfeld, D.; Goldkorn, A. Liquid Biopsy in Prostate Cancer: Circulating Tumor Cells and Beyond. Cancer Treat. Res. 2018, 175, 87-104. [CrossRef] [PubMed]

138. Zhang, J.; Ahn, K.S.; Kim, C.; Shanmugam, M.K.; Siveen, K.S.; Arfuso, F.; Samym, R.P.; Deivasigamanim, A.; Lim, L.H.; Wang, L.; et al. Nimbolide-Induced Oxidative Stress Abrogates STAT3 Signaling Cascade and Inhibits Tumor Growth in Transgenic Adenocarcinoma of Mouse Prostate Model. Antioxid. Redox Signal. 2016, 24, 575-589. [CrossRef] [PubMed]

139. Zhang, J.; Sikka, S.; Siveen, K.S.; Lee, J.H.; Um, J.Y.; Kumar, A.P.; Chinnathambi, A.; Alharbi, S.A.; Basappa; Rangappa, K.S.; et al. Cardamonin represses proliferation, invasion, and causes apoptosis through the modulation of signal transducer and activator of transcription 3 pathway in prostate cancer. Apoptosis 2017, 22, 158-168. [CrossRef] [PubMed]

140. Lee, J.H.; Kim, C.; Baek, S.H.; Ko, J.H.; Lee, S.G.; Yang, W.M.; Um, J.Y.; Sethi, G.; Ahn, K.S. Capsazepine inhibits JAK/STAT3 signaling, tumor growth, and cell survival in prostate cancer. Oncotarget 2017, 8 , 17700-17711. [CrossRef]

141. Shanmugam, M.K.; Ong, T.H.; Kumar, A.P.; Lun, C.K.; Ho, P.C.; Wong, P.T.; Hui, K.M.; Sethi, G. Ursolic acid inhibits the initiation, progression of prostate cancer and prolongs the survival of TRAMP mice by modulating pro-inflammatory pathways. PLoS ONE 2012, 7, e32476. [CrossRef] [PubMed]

142. Shanmugam, M.K.; Manu, K.A.; Ong, T.H.; Ramachandran, L.; Surana, R.; Bist, P.; Lim, L.H.; Kumar, A.P.; Hui, K.M.; Sethi, G. Inhibition of CXCR4/CXCL12 signaling axis by ursolic acid leads to suppression of metastasis in transgenic adenocarcinoma of mouse prostate model. Int. J. Cancer 2011, 129, 1552-1563. [CrossRef] [PubMed]

143. Shanmugam, M.K.; Rajendran, P.; Li, F.; Nema, T.; Vali, S.; Abbasi, T.; Kapoor, S.; Sharma, A.; Kumar, A.P.; Ho, P.C.; et al. Ursolic acid inhibits multiple cell survival pathways leading to suppression of growth of prostate cancer xenograft in nude mice. J. Mol. Med. 2011, 89, 713-727. [CrossRef] [PubMed]

144. Chiang, P.K.; Tsai, W.K.; Chen, M.; Lin, W.R.; Chow, Y.C.; Lee, C.C.; Hsu, J.M.; Chen, Y.J. Zerumbone Regulates DNA Repair Responding to Ionizing Radiation and Enhances Radiosensitivity of Human Prostatic Cancer Cells. Integr. Cancer Ther. 2018, 17, 292-298. [CrossRef] [PubMed]

145. Jorvig, J.E.; Chakraborty, A. Zerumbone inhibits growth of hormone refractory prostate cancer cells by inhibiting JAK2/STAT3 pathway and increases paclitaxel sensitivity. Anti-Cancer Drugs 2015, 26, 160-166. [CrossRef] [PubMed]

146. Sun, Y.; Sheng, Q.; Cheng, Y.; Xu, Y.; Han, Y.; Wang, J.; Shi, L.; Zhao, H.; Du, C. Zerumbone induces apoptosis in human renal cell carcinoma via Gli-1/Bcl-2 pathway. Die Pharm. 2013, 68, 141-145.

147. Alsaab, H.O.; Sau, S.; Alzhrani, R.M.; Cheriyan, V.T.; Polin, L.A.; Vaishampayan, U.; Rishi, A.K.; Iyer, A.K. Tumor hypoxia directed multimodal nanotherapy for overcoming drug resistance in renal cell carcinoma and reprogramming macrophages. Biomaterials 2018, 183, 280-294. [CrossRef] [PubMed] 
148. Shanmugam, M.K.; Rajendran, P.; Li, F.; Kim, C.; Sikka, S.; Siveen, K.S.; Kumar, A.P.; Ahn, K.S.; Sethi, G. Abrogation of STAT3 signaling cascade by zerumbone inhibits proliferation and induces apoptosis in renal cell carcinoma xenograft mouse model. Mol. Carcinog. 2015, 54, 971-985. [CrossRef] [PubMed]

149. Henrikson, N.B.; Morrison, C.C.; Blasi, P.R.; Nguyen, M.; Shibuya, K.C.; Patnode, C.D. Behavioral Counseling for Skin Cancer Prevention: Evidence Report and Systematic Review for the US Preventive Services Task Force. JAMA 2018, 319, 1143-1157. [CrossRef]

150. Murakami, A.; Tanaka, T.; Lee, J.Y.; Surh, Y.J.; Kim, H.W.; Kawabata, K.; Nakamura, Y.; Jiwajinda, S.; Ohigashi, H. Zerumbone, a sesquiterpene in subtropical ginger, suppresses skin tumor initiation and promotion stages in ICR mice. Int. J. Cancer 2004, 110, 481-490. [CrossRef] [PubMed]

151. Al-Zubairi, A. Anti-proliferative activity of zerumbone against tumour cell lines. OnLine J. Biol. Sci. 2018, 18, 123-129. [CrossRef]

152. Shyanti, R.K.; Sehrawat, A.; Singh, S.V.; Mishra, J.P.N.; Singh, R.P. Zerumbone modulates CD1d expression and lipid antigen presentation pathway in breast cancer cells. Toxicol. In Vitro 2017, 44, 74-84. [CrossRef] [PubMed]

153. Dermani, F.K.; Amini, R.; Saidijam, M.; Pourjafar, M.; Saki, S.; Najafi, R. Zerumbone inhibits epithelial-mesenchymal transition and cancer stem cells properties by inhibiting the $\beta$-catenin pathway through miR-200c. J. Cell. Physiol. 2018, 233, 9538-9547. [CrossRef] [PubMed]

154. Lv, T.; Zhang, W.; Han, X. Zerumbone suppresses the potential of growth and metastasis in hepatoma HepG2 cells via the MAPK signaling pathway. Oncol. Lett. 2018, 15, 7603-7610. [CrossRef] [PubMed]

155. Jegannathan, S.D.; Arul, S.; Dayalan, H. Zerumbone, a Sesquiterpene, Controls Proliferation and Induces Cell Cycle Arrest in Human Laryngeal Carcinoma Cell Line Hep-2. Nutr. Cancer 2016, 68, 865-872. [CrossRef] [PubMed]

156. Yan, H.; Ren, M.Y.; Wang, Z.X.; Feng, S.J.; Li, S.; Cheng, Y.; Hu, C.X.; Gao, S.Q.; Zhang, G.Q. Zerumbone inhibits melanoma cell proliferation and migration by altering mitochondrial functions. Oncol. Lett. 2017, 13, 2397-2402. [CrossRef]

(C) 2019 by the authors. Licensee MDPI, Basel, Switzerland. This article is an open access article distributed under the terms and conditions of the Creative Commons Attribution (CC BY) license (http:/ / creativecommons.org/licenses/by/4.0/). 